\title{
Investigation of Freedom in Its Ontological Sense
}

\author{
Catherine V. Biricheva \\ Institute of Philosophy and Law, Ural Branch of the Russian Academy of Sciences, 620990, Russia \\ Yekaterinburg S. Kovalevskoj, 16; Email: e.v.biricheva@mail.ru
}

\section{Doi:10.5901/mjss.2015.v6n5s3p11}

\begin{abstract}
The article considers the category of freedom in its ontological sense. Due to the plural character of contemporary situation, within which person finds him- or herself lost without any reliable ground, it is necessary to investigate the question of freedom of the human "I", although many philosophers of the past had already investigated this problem in diverse ways. We conceive the question of freedom as deep and, at the same time, multiple one. Methodologically, the current article poses this question in different ways, taking into consideration the individual level of being. This phenomenological approach (in its wide sense) allows to understand ontological ground of freedom due to varying the way to pose a question while considering the ultimate experiencing of being through such "existentials", as human finitude, responsibility for the "Other", happiness and destiny. We also rethink the ontological situation of searching for the sense of freedom, trying to trace a kind of a "dialog" between contemporary philosophers and such thinkers of the past, as Plato, B. Spinoza, G.W. Leibniz, I. Kant, G.W.F. Hegel, M.M. Bakhtin, M. Heidegger. This discussion is organized not in "retrospective" fashion, but in a "problematical" one.
\end{abstract}

Keywords: freedom, being, finitude, responsibility, destiny.

\section{Introduction}

The $20^{\text {th }}$ century could be characterized as the age of embodiment the ideas of human rights and freedoms in the legislative field. We deal with the development of the virtual reality space at the beginning of the $21^{\text {st }}$ century. Improvement of transport, rapid evolution of technical vehicles and technologies are also among contemporary features. These features seem to make human free at last. Despite this, the question of freedom remains one of the most topical today. It is raised pointedly at diverse levels, ranging from the problem of freedom of entire nation or country within international relations to the matter of freedom of the concrete "I" in the extension of his or her own existential situation.

Being topical and inescapable, the question of freedom can be posed in various ways taking into consideration, that we find ourselves in the given situation, co-existing with the others and limited by our lifetime. So what does it mean "to act freely"? Can we act freely without being in charge of the others' freedom? Which choice, always limited by time, could be named "free"? The purpose of this research is not only to show a wide coverage of the possible range of positing the problem of freedom, but also to make an effort of paying attention exactly to the multiple way to pose a question at "ontological level". In attempting to clarify the essence of freedom itself, it is useful to distinguish "ontological freedom, in the above sense, and more ideologically significant conceptions of political freedom" (Crowe, 2009, p. 78), and to make difference between freedom, liberty and independence. Let us focus on the first one, because without understanding of freedom in its ontological sense investigation of other constituents of the problem seems to be sketchy.

\section{Literature Review}

The problem of freedom appears firstly in such Socratic dialogs, written by Plato, as Republic, Statesman and Laws, in Classical Greece. The confrontation between freedom and fate is also one of the fundamental subjects of Ancient tragedies. The problem of freedom-fate dichotomy transforms into the question about freedom-necessity correlation in Medieval metaphysics and reaches its apogee in the famous Renaissance dispute on free will between Martin Luther and Erasmus Roterodamus. This issue gets its new turn in the $17^{\text {th }}-18^{\text {th }}$ centuries due to elaboration of ideas of sense of justice and of subject's autonomy in works of such Enlightenment philosophers, as T. Hobbes, J. Locke, I. Kant. We can find further development of this problematic field in late classical and early non-classical philosophy of G.W.F. Hegel, S. Kierkegaard, A. Schopenhauer, F. Nietzsche, which understand freedom through its interrelations with the categories of process, becoming, power, will and life. In discussing human dependence on society, type of economic relations, moral standards, irrational desire, which is produced by unconsciousness, S. Freud and K. Marx impugn subject's freedom. 
It becomes clear, that classical "thinking consciousness" cannot longer act as an autonomous "ground of being", when metaphysics gets overcome on different paths by such influential philosophical approaches, as analytical, phenomenological and structuralist ones. In its turn, pluralism seems to lift restrictions and to make a human freer. In fact, the contemporary person finds itself lost without any reliable ground or, at least, some reference point. That is why researches feel exigency to pose questions about freedom again and again. They frequently refer to the texts by K. Marx, M. Merleau-Ponty, E. Levinas, I. Berlin, E. Fromm, J. Derrida, J. Habermas and other influential non-classical thinkers (Crowe, 2009, Rasheed, 2002, Vaughan, 2010).

Nevertheless, investigation of the ontological sense of freedom appeals to the necessity not only to research the concepts of freedom offered by the contemporary philosophers, but also to trace their "dialog" with such thinkers of the past, as Plato, B. Spinoza, G.W. Leibniz, I. Kant, G.W.F. Hegel, M. Heidegger, J.-P. Sartre. Realization of this intention not as "retrospective", but as "problematical" one is also among the main objectives of the current research.

\section{Research Methodology}

The consequences of global events of the $2^{\text {th }}$ century have lead philosophical thought of almost all traditions to the denial of freedom and to the refusal of any attempt to look for it. Nevertheless, we will not be able to accept the absence of freedom until we exist as humans. Even if we realize the impossibility of pure freedom in a rational way, according to the strong reasons, which one could argue, - some inner irrational source will stand against this proposition.

Thereby, research approaches of rational/logical "corps" (analytical movement) will hardly succeed in searching for the sense of freedom within the contemporary conditions. Description of freedom as a state of mind cannot be given "theoretically". The phenomenon of freedom cannot be detected in "objective" way, which would not depend on any "starting point" and which would ignore an individual dimension. That is why the purpose of this research is neither to make the next attempt to give definition to the category of freedom nor to clarify it using logical analysis of language. It is rather to show, that the question of freedom is deep, and it can be elaborated only from within the situation of experience of being. The designated way to investigate freedom requires existential methodology and its possibilities to consider the ultimate ontological situation.

When we say "existential", we do not mean to use the ideas of only straight understood Existentialism in our investigation. "Existential aspects" are the most immanent moments, which take place within the unique experience of being, where we face with finitude, fear of death, loneliness, abandonment, desolation, and other "existentials" familiar to everyone. According to M. Bakhtin, "philosophy of such a kind cannot proceed by constructing universal concepts, propositions, and laws about this world of answerably performed act..., but can only be a description, a phenomenology of that world. An event can be described only participative" (Bakhtin, 1921/1999, p. 31-32). In this way, it is rather productive to refer to the texts of Continental philosophy, on one hand, and to exercise phenomenological description of individual experiencing of being, on the other.

It is important to pay attention to the very way of posing a question: it already includes a possibility of answering and lightens this or that way to answer. Besides, productive extracting of sense within the given conditions becomes possible during varying, moving an angle of view, considering the problem from different sides. So, unfolding a thought from its conditions will allow us to see freedom from within the ultimate ontological situation.

\section{Findings and Discussion}

\subsection{What is "the given?}

We are talking about the so-called situation of "minimum of being" (G. Deleuze) or "threat of nonbeing" (P. Tillich). Every person faces this threat at the ontological level in this or that form. Threat of nonbeing appears due to the "discovery" of finitude, although it does not necessary get the form of "fear of death" in each concrete case (we may be afraid of guilt, meaninglessness, groundlessness, chaos, loneliness etc.). Having discovered our finitude, we see an ontological claim to get on time. The necessity to understand this claim rises in front of human (what should I do timely and how?). It makes us distinguish the concrete productive among the fullness of being. It occurs due to asking questions, i.e. it leads us out to the level of understanding. A child gets an "ontological" birth, not at the same time with the "physical" one in this way. It happens only when a child finds himself or herself finite (earthborn) at the first time. This conversion to the existence as an ontological creature is distinctly notable: child begins to ask questions after "mechanically" used affirmative expressions of manifestation, designation and signification due to the necessity of looking for sense beyond the mechanics of language's dimension. 
Minimum of being turns out to be not only a "takeout" of all corporeal consolidations, language structures, and psychological stratifications, but it is also the ultimate given. The "gift of death" (J. Derrida) has positive sense because finitude, which is minimum in itself, lightens maximum of possibilities and helps to form a path of self-fulfillment. So, when we face finitude as the ultimate given, it motivates us to ask and to think. This situation has a nature of the task. Besides "the given", there are other constituents of task: "to find" and "solution", i.e. the question, that we pose accepting "the given", and the way of solution, which we are searching for in process of understanding the given conditions. However, what do we see as "the given"?

There are some circumstances, which penetrate into our consciousness (for example, during childhood, we internalize social stereotypes faster, then conceiving of the necessity to act according to the own ontological ground) and which can interfere to catch sight of the given as enough. It was brilliantly showed by structural psychoanalysis that most of the people think through category of "the lack" (J. Lacan): it seems, that we always need something else (something missed) to reach "complete happiness". However, it cannot be achieved neither by means of accumulation of things nor due to the "consuming" of works of art, educational services or relationships, if we are aimed at filling the emptiness (the lack) of being in modus of "having" (Fromm, 1976/2008). Yet Kierkegaard has distinctly formulated the idea of fullness of the given: everything needed is the "material" for conceiving, and it is already given to us within our being, - the problem is to see everything surrounding us as enough (Kierkegaard, http://dx.doi.org/10.1017/CBO9780511809712, 1843/2006). Heidegger says, that before considering the question "What shall we do?" we should ponder this: "How must we think?" (Heidegger, 1962/1977, p. 40). At this moment, these philosophers make an emphasis on the idea, that making an effort is required to think instead of being brought under control by Discourses, ideologies, stereotypes or representations.

All this says that it is productive not to act immediately in answer to what happens around, but to delay in order to stop our natural disposition to react in order to conceive the given. We can act productively only taking in account the given, understood in modus of the enough. However, then, where is freedom, if everything is already given within our being?

\subsection{What does freedom refer to?}

Philosophical view deals with the fundamental "Human - World" interrelation. Thus, to put our question philosophically is to set a goal of investigating the "location" of freedom within this interrelation. Freedom turns out to be on "the weighting pan" of the human "l" in the philosophy of Descartes and Kant due to autonomy and primacy of the "thinking consciousness". In this case, diversity of the world gets questioned, because we cannot reduce it to the dependent objective worldview, constructed by classical subject. On the other hand, in case of ontological activity's full transition to another "weighting pan" of the world (as it happens, for example, in post-structuralism, which acknowledges the total authority of Discourse) not only freedom gets questioned, but existence of "I" is rejected.

Generally, we may state, that most of the contemporary thinkers of the postmodern wing deny freedom-itself. For instance, M. Foucault works out the concept of discoursive practice. These practices could be understood in the way of the investigation this or that "object". However, the author offers to consider "object" only as dependent: everything is captured and conditioned by the given order. It means that this "object" does not exist before we begin to apply these practices. Relative independence could be supposed only for Discourses. Nevertheless, by Foucault, any Discourse-itself is conditioned by historical features (social, linguistic, economic structures) of the concrete age (Foucault, 1966/2002).

However, such postmodernist authors, as G. Deleuze and F. Guattari, come to understanding of the possibility of freedom exactly due to the arrangement of Discourses' orders, which may offer virtual space for action. Dependent position about discursive systems is overcome using "production of sense" in the process of creation at the ontological level. Of course, this activity could not be named a centralized or a fixed one. Nevertheless, it becomes free from Discourses' authority due to the ability to change and slide (to slip from any definiteness). The methodology of schizoanalysis, worked out by these French thinkers, traces possible paths to escape the processes of "optimization", which capture "I" within the psychoanalytical Discourse (Deleuze \& Guattari, 1972/2000). Freedom gets its realization in the modus of production of sense based on the "material" of diverse Discourses (from literature and philosophy to psychology and biology) in works of Deleuze (Deleuze, 1968/1994, Deleuze, 1969/1990 The Logic Of Sense). Thus, freedom could be considered only in becoming within the contemporary situation of "groundlessness" and total pluralism. It allows the ontological activity to slip from the authority of discursive orders and to embody one's own way of being in multidimensional space of virtuality, producing itself as a border-in-becoming between "Human" and "World", as a dynamical constructing of the very inter-relation.

Deleuzian way to understand freedom rather resembles that of Leibniz, which grows, in its turn, from the Spinozian position. It should be noticed, that Spinoza, in contradiction to his coeval thinkers, is aware of a heterogeneous nature of 
consciousness. The last exists as a perceiving one. Consequently, it is exposed to outer impact, becoming fragmentary and losing its autonomy. However, Spinoza thinks, that together with the "passive" part of the consciousness, which is addicted to suffer, there is a source of activity. The goal is to set this positive power free, even if we understand that absolute freedom could not be achieved due to the diversity of things, with which we are to interact accepting suffering.

The reason is opposed to consciousness in Spinozian philosophy. Consciousness is understood as a place of accumulation of different useful and worthless things, which get inside naturally by interacting between the human and the world. Such consciousness cannot be homogeneous, but reason links all the pieces being an internal activity (Spinoza B., www.gutenberg.org/files/3800/3800-h/3800-h.htm, 1677/2009). Together with fragmentary and passivity of consciousness, there is a reason, which discovers "good compositions" and grasps "common notions" in its becoming to make human unfold activity from the inside (Deleuze, 1970/1988, p. 55-56).

Spinoza asks: "How should we look on the Necessary?" It is possible to avoid and to overcome "everything that involves sadness" (Deleuze, 1970/1988, p. 72) only in the positivity of constructing the relations with life. For Spinoza, to be free means to act. As soon as grasping of the necessity of suffering occurs, an internal positive activity can be discovered: while understanding the state of affairs in this or that way we already act freely.

The same idea substantiates Leibnizian monadology. According to thinker's formula, "activities and passivities are mutual" (Leibniz, http://home.datacomm.ch/kerguelen/monadology/monadology.html, 1714/1898). Leibniz means, that suffering [passivity] can be overcome by unfolding of internal conceiving activity. The concept of freedom-in-action is also "proportionate" to Leibnizian "pre-established harmony". God chooses the best universe among an infinite number of possible variations (Leibniz, 1714/1898). However, hence, is there any place for the unique activity or everything is predetermined (even in the best way)?

Harmony is pre-established by God in the universe and in every "I" that expresses this universe as its tiny "mirror". However, we already can choose between conceiving and not conceiving of the universe as harmonically established, between clarifying and not clarifying of our indistinct perceptions, between actualizing and not actualizing of given faculties. God has folded "Appetitions" within every monad, and the ability of self-transcendence within each unique way to be (way to express the universe from every special point of view). Then, freedom begins with conceiving of these faculties and their eminence. "I" is free "not because it is determined from within, but because every time it constitutes the motive of the event that it produces" (Deleuze, 1988/1993, p. 72).

Deleuze analyzes these concepts and finds out an interesting paradox. Freedom is not what is threatened. "Rather, it is morality... Morality consists in this for each individual: to attempt each time to extend its region of clear expression, to try to augment its amplitude, so as to produce a free act that expresses the most possible in one given condition or another" (Deleuze, 1988/1993, p. 73). Before deciding, everyone should ask: "Have I chosen the side where the amplitude is maximal, the side where my region goes the furthest?" (Deleuze, 1988/1993, p. 73).

\subsection{How does freedom relate to responsibility?}

Freedom could be discovered as an internal action, although "I" itself is heterogeneous and changeable. However, we cannot ignore the ethical problem mentioned by Deleuze. Will my act, which serves purposes of self-development and self-eminence, turn good for others every time? We should consider this question, because our methodology presumes taking in account not only "I's" finitude, but also "Other's" one. "Other" is the other "l", which finds himself or herself in a similar ontological situation, where he or she also has the concrete given point of view, "singularity and irreplaceability" of the own place in the world (Bakhtin, 1921/1999, p. 41).

"Other" is crucial for us due to the nature of "structure which conditions the entire field [of perception]" and "which renders perception possible" (Deleuze, 1969/1990 Michel Tournier and the World without Others, p. 309). Sartre underlines the importance of "Other" too. "When we say that man handles himself, we do not mean that he is responsible only for his individuality, but that he handles all men... Our responsibility is thus much greater than we had supposed, for it concerns mankind as a whole" (Sartre, www.marxists.org/reference/archive/sartre/works/exist/sartre.htm, 1946/2005).

Here we may notice Kantian tone although Sartre criticizes Kant for his pre-determined apriority. Conveying freedom from the sphere of pure reason to the area of acts, Kant offers famous imperative: "So act that the maxim of your will could always hold at the same time as a principle of a universal legislation" (Kant, 1788/2002, p. 45). This principle consists in individual responsibility for co-existing with others. "I" discovers "Other", which is also realizing free way of being: "willing freedom, we discover that it depends entirely upon the freedom of others and that the freedom of others depends upon our own" (Sartre, www.marxists.org/reference/archive/sartre/works/exist/sartre.htm, 1946/2005). 


\subsection{Where does pure freedom inhabit?}

Another deep question could be posed in light of our inescapable "bordering" and "sharing of being" with others. On which ground can we affirm individual freedom then? To answer this question, it is useful to consider freedom through three "levels of reality". Freedom will represent the absence of physical limitation at the physical level. For the concrete person, it will mean independence from another opinion, from oppression, from ideology, and freedom of religion, of conscience, of speech, etc. at the psychological level. Nevertheless, genuine freedom can be found only at the ontological level. One could have no freedom of movement; ideology, definite religious representations or social stereotypes might be imposed. However, a human can remain free from the inside.

Even being dependent on something external, one can be truly free only in ontological plan, where no submission can be possible fundamentally, no matter, how ontological space is understood (from sphere of absolute truth to ontological solitude). Each one, only on one's own, can exit to the feeling of "minimum of being" and, consequently, to pose the own question and to answer in a unique way.

Hegel discusses the same when he focuses on the situation of "lord and bondsman" (Hegel, 1807/1977, pp. 115119). A true lord of being faces up to the "treat of nonbeing" and conceives this situation, doubting if there might be him at all. I.e. even "bondsman", which is dependent physically and psychologically, has possibility of freedom at the ontological level, because, besides finitude, there is always unique topological position given to each one within being. It allows everyone to unfold individual freedom in process-action of thinking.

The moment of our first exit at the level of conceiving of the ontological situation marks the transformation of the entire "familiar" world to the opposite one. Even "hierarchy of needs" inverts. We can bear hunger, we can find the strength to confront being misunderstood by others. However, as soon as we have discovered our finitude, we cannot allow ourselves to lose aspiration to self-realization, i.e. to the most fundamental need. Even formal satisfaction of all the other needs will not make us happy if there is no ability to do things we love most of all (to practice work, which fulfills our life with sense).

Thinking of the ideal state, Plato provides the same idea. If every citizen accords his destiny and develops faculties in his favorite business, everyone will be happy (Plato, 380BC/1991, pp. 97-125). So the following thought visits: many human troubles come from the situation, that not many people come to grasping of their destiny, just explaining their "absence" of happiness by having a "lack" of the given and trying to achieve the fullness of being by means of accumulating things. Hence, destiny can be named the only reliable ground of being for every thinking creature. After Plato, we are inclined to say that reaching genuine happiness is a criterion for grasping and realizing of destiny.

Tillich understands human as "finite freedom", and this idea is undoubtedly close to our position, within which we discover freedom through the category of "finitude". "Freedom not in the sense of indeterminacy but in the sense of being able to determine himself through decisions in the center of his being. Man, as finite freedom, is free within the contingencies of his finitude. However, within these limits he is asked to make of himself what he is supposed to become, to fulfill his destiny" (Tillich, 1952/1980, p. 52). Ontological situation connects finitude, freedom, destiny and happiness in a single "knot". The task of being is to make a constant effort of holding its connection.

Heidegger also rethinks notions of "claim of Being" and "appeal". When being appears in its entire fullness, not only finiteness of "l", but also its openness into this ontological space can be discovered. To fulfill our destiny with the concrete sense we are to listen attentively to the "claim of Being", and we are to gaze hardly into our way to be, which can be opened in every action. Our ontological task is "to correspond at all to Being and its claim, and, in corresponding, to belong to Being" (Heidegger, 1962/1977, p. 41).

\section{Concluding Remarks}

The article shows that pure freedom can be discovered only as a way of realization of the internal activity in the process of constructing "I - World" interrelation. Neither freedom nor internal activity can be fixed or caught "substantively", because they can be practiced only "here and now" within every unique way of being and can be experienced only at the ontological level. The intensity of creating of sense and the degree of openness to the individual experience of being give an opportunity to self-realization by way of free and happy creature. Following one's "appeal" opens a vast for free choice in ontological dimension, which, in its turn, cannot be affected neither by theoretical constructions nor by formal conventionalities making us independent from any external conditions. Understanding of the own freedom as an ontological phenomenon at existential level initiates continuing efforts of self-realization and self-transcendence, which only make us - humans - who we are. 


\section{References}

Bakhtin, M.M. (1921/1999) Toward a Philosophy of the Act. General Editor M. Holquist. Translation and Notes by V. Liapunov. Austin: University of Texas Press. Slavic Series no. 10.

Crowe, J. (2009) Explaining Natural Rights: Ontological Freedom and the Foundations of Political Discourse // New York University Journal of Law and Liberty, 2009, Vol.4, pp. 70-109.

Deleuze, G. (1968/1994) Difference And Repetition. Translated by P. Patton. New York: Columbia University Press.

Deleuze, G. (1969/1990) Michel Tournier and the World without Others // The Logic Of Sense. Edited by C.V. Boundas. Translated by M. Lester with C. Stivale. London: The Athlone Press, pp. 301-321.

Deleuze, G. (1969/1990) The Logic Of Sense. Edited by C.V. Boundas. Translated by M. Lester with C. Stivale. London: The Athlone Press.

Deleuze, G. (1970/1988) Spinoza: Practical Philosophy. Translated by R. Hurley. San Francisco: City Lights Books.)

Deleuze, G. (1988/1993) The Fold: Leibniz and the Baroque. Foreword and translation by T. Conley. London: The Athlone Press.

Deleuze, G., Guattari F. (1972/2000) Anti-Oedipus. Capitalism and Schizophrenia. Translated by R. Hurley, M. Seem and H.R. Lane. Minneapolis: University of Minnesota Press.

Foucault, M. (1966/2002) The Order Of Things: An Archaeology of the Human Sciences. English translation. London, New York: Routledge Classics.

Fromm, E. (1976/2008) To Have or to Be? London, New York: Continuum.

Hegel, G.W.F. (1807/1977) Phenomenology of Spirit. Translated by A.V. Miller. Oxford, New York, Toronto, Melbourne: Oxford University Press.

Heidegger, M. (1962/1977) The Turning // The Question Concerning Technology and Other Essays. Translated and with Introduction by W. Lovitt. New York, London: Garland Publishing, Inc, pp. 36-49.

Kant, I. (1788/2002) Critique of Practical Reason. Translated by W.S. Pluhar. Introduction by S. Engstrom. Indianapolis, Cambridge: Hackett Publishing Company, Inc.

Kierkegaard, S. (1843/2006) Fear and Trembling. Edited by C.S. Evans, Edited by S. Walsh. Cambridge: Cambridge University Press. Book DOI: http://dx.doi.org/10.1017/CBO9780511809712

Leibniz, G.W. (1714/1898) The Monadology. English translation by Robert Latta, 1898. Available at: http://home.datacomm.ch/ kerguelen/monadology/monadology.html (accessed May 29, 2015)

Plato (380BC/1991) Republic. Translated with notes and interpretive essay by A. Bloom. Second Edition. Basic Books: A Division of Harper Collins Publishers. ISBN 0-465-06934-7 (second edition paper)

Rasheed, S. (2002) The Existential Concept of Freedom for Maxine Greene: The Influence of Sartre and Merleau-Ponty on Greene's Educational Pedagogy // Philosophy of Education, 2002, 394-402.

Sartre, J.-P. (1946/2005) Existentialism Is A Humanism. HTML Markup: by Andy Blunden 1998; proofed and corrected February 2005. Available at: https://www.marxists.org/reference/archive/sartre/works/exist/sartre.htm (accessed May 24, 2015)

Spinoza, B. (1677/2009) The Ethics. Translated from the Latin by R.H.M. Elwes. E-book. Posting Date: May 28, 2009. Available at: http://www.gutenberg.org/files/3800/3800-h/3800-h.htm (accessed May 29, 2015)

Tillich, P. (1952/1980) The Courage to Be. New Haven, London: Yale University Press.

Vaughan, F. (2010) Identity, Maturity and Freedom: Transpersonal and Existential Perspectives // Journal of Transpersonal Research, 2010, Vol.2 (1), pp. 2-9. 